\title{
The Use of Schema Activation Strategy in Teaching Reading Comprehension at The Second Grade Students of Islamic Junior High School
}

\author{
Hidayati $^{1}$, Rima Rahmaniah ${ }^{2}$, Titin Suryani ${ }^{3}$ \\ ${ }^{1,2,3}$ English Language Education, Muhammadiyah University of Mataram, Indonesia \\ ${ }^{1}$ hidayatiumm2004@gmail.com, ${ }^{2}$ rimarahmaniah172@gmail.com, ${ }^{3}$ titinsuryani@gmail.com
}

\begin{abstract}
Keyword:

Schema activation strategy;

Reading comprehension.

Reading is one of the important skills that the students have to master. However, many students have difficulties in comprehending the reading text. To solve this condition, the researcher used schema activation strategy to help students understand reading comprehension. The purpose of this research was to investigate whether the use of schema activation strategy is effective or not in teaching reading comprehension at the second-grade students of MTs Tarbiyatul Mustafid. This study was quasi experimental design using two classes were VIII-B class was taken as an experimental class and VIII-A was taken as control class. The population of this research involved 60 students from the second grade in MTs Tarbiyatul Mustafid Batu Rimpang. By using purposive sampling, the researcher took the students as a sample. In collecting the data, this study used pre-test, treatment, and post-test as the data collection procedure then followed by analyzing the data by using t-test formula. Then the result of statistical analysis of t-test in this research was 2.85 . It was higher that critical values for $\mathrm{t}$ - table in degree of freedom (df) of 58 is $2.021(0.05 \%)$ and 2.704 $(0.01 \%)$. The researcher concludes that mean score before and after taught by using schema activation strategy has difference. It means the alternative hypothesis (ha) was accepted. The use of schema activation strategy in teaching reading comprehension at the second grade students of MTs Tarbiyatul Mustafid Batu Rimpang is effective.
\end{abstract}

Article History:

Received: 10-02-2019

Revised : 19-03-2019

Accepted: 20-04-2019

Online : 30-04-2019

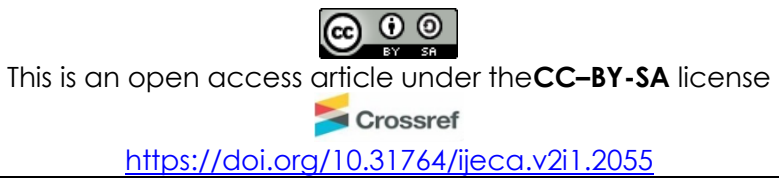

\section{A. INTRODUCTION}

Language is a tool of communication used by people to connect each other. By language they will be easy to express their ideas, opinions, feelings, etc (Basyarudin, 2015). There are many languages in the world. English is one of the languages used as international language for communication. Many people want to learn English in order to be able to communicate well and to be able to go abroad when they have mastered English. In Indonesia, English is considered as foreign language and is taught formally from elementary until university level. In order to mastering English there are four skills that should be mastered, they are: listening, speaking, reading, and writing. Reading is a skill that is important to be taught because according to (Ferlito et al., 1996). Reading is bringing and getting meaning from the printed or written 
material. Reading comprehension is the ability to understand what has been read (Zimmerman, 1967).

However, based on the researcher observation in MTs. Tarbiyatul Mustafid, most of the students still have difficulties in comprehending an English text, getting information from the text, finding the main ideas, answer to the questions based on the text and making conclusion of the text. The facts indicate that they had low ability in comprehending English text so their reading score is average low. It is because reading in the classroom only focus on asking students to read the text and answering the question based on the text without facilitating them to comprehend texts properly. That is why the students feel bored and not motivated in the subject which demands the students to read.

Relate to the problem above, it is possible to the teacher to find the appropriate strategy to teach reading strategy that can make students easy to understand in learning and encourage students to be easily understand the reading material. The researcher tries to offer the strategy is called schema activation strategy. Schema Activation Strategy is a strategy which focuses on activating students' background knowledge. Such steps as building interest and attention, assessing prior knowledge and exploring keywords, building connection between students prior knowledge and the new material, and comprehending the new material were implemented in the teaching and learning process of reading. They influence much on the success of reading a text. According to Mardianti (Mardianti et al., 2016) schema activation strategy is a way of reading where the readers are expected to use a strategy to activate his/her own prior knowledge when they read English text or passage.

Relate with the study, there are some previous conducted the using of schema activation strategy, they are: First, Kurnia (2014) entitled "Improving the reading comprehension of grade VIII students at SMPN 1 Melati using Schema Activation Strategy". The result of the research revealed that the use of schema activation strategy successfully to improve the student's reading comprehension. Second, Fazri, Muhamad Alif (2013) entitled "Using Schema Activation Strategy to improve reading comprehension of grade 8B". The result of two cycles showed that that the use of schema activation strategy is effective to improve the student's reading comprehension. It's support by qualitative data which show that the students were able to use their prior knowledge to understand the text. The last Veti Mardianti (2014) entitled “Improving Student's Reading Comprehension through Schema Activation Strategy" the result by using schema activation strategy can significantly improve the student's reading comprehension.

From the explanation above, the researcher wants to conduct the research entitle "The use of schema activation strategy in teaching reading comprehension at the second grade students of MTs Tarbiyatul Mustafid".

\section{B. METHODS}

The research design of this study was Quasi Experimental Design. According to Sugiyono (Sugiyono, 2013) stated "it is developing from the experimental design. This design has a control group, but that group does not have full functions to control the variables outside of the research implementation". The researcher had investigated that the use of schema activation strategy in teaching descriptive text at the second grade student of MTs Tarbiyatul Mustafid in academic year 2016/2017, in that research the students was divided into two groups namely experimental and control group, only experimental group was taught by using schema activation strategy while the control group was not used. 
The population is the group of people we wanted to generalise to (Muijs, 2012). The population of this study was all the students at the second grade students of MTs. Tarbiyatul Mustafid in academic year 2016/2017 who have two classes were A class (30 students) and B class (30 students) so the total of number whole population was 60 students.

According to (Suharsimi;, 2013) if the population more than 100 person, we taken only $10 \%$ - 15\%, 20\% - 25\% (or more) of it can be taken but If the population less than 100 person, we take all of them as a sample. The sample of this study was all the students at the second grade students of MTs. Tarbiyatul Mustafid in academic year 2016/2017 who have two classes those are A class (30 students) and B class (30 students) so the total of the sample is 60 students.

Based on the statement above the sample of this study took by using purposive sample. This technique is usually done becuase of some considerations, such as the limit of time, energy that is why cannot take samples which is large and far (Suharsimi, 2013). Sugiyono (Sugiyono, 2017) says that instrument is a means to know the nature and social phenomenon that wants to observe. In this research, the researcher used the reading test in form of 25 numbers multiple choice. It was supposed to know the ability of the students before and after the researcher used schema activation strategy. The text about descriptive text in different story in question. The pre-test and post-test are descriptive text about person, place, animal and things. Both the test has same types of question. Each number of the test would be score 4, if the students answer correctly they will get score and if they answer is wrong they will get score 0 . In this research used test as an instrument of collect the data, and the data was collect by gave pre-test and a post-test to the experimental group and control group.

\section{RESULT AND DISCUSSION}

The analysis of the data in this research is aimed to find out mean scores analysis, is it referred to the score of $\mathrm{t}$ - test 2.85. Before the researcher check the table distribution. Firstly, the researcher determine the degree of freedom (df) that is $x+y-2=30+30-2=58$. Based on the table of level significance have been poin ted out, the coefficient $t$-test is directly checked on the table of $t$ distribution. Based on the table, the critical value of $t$-table on the level of significance $t 0.05 \%$ is 2.021 and $t 0.01 \%$ is 2.704 . So, it is found that $2.85>2.021$ and 2.704 .

Based on the data analysis above, it was found that the result of t-test is higher than t-table. It means that alternative hypothesis which stated that the use of schema activation strategy was effective in teaching reading is accepted. Meanwhile the null hypothesis which stated that schema activation strategy has not effect in teaching reading is rejected

The researcher has investigated the use of schema activation strategy in teaching reading comprehension. Based on the research question formulated in chapter I, this research is aimed to investigate whether the use of schema activation strategy effective or not in teaching reading comprehension. Referring to data interpretation that has been presented above, it was found the deviation score of pre-test and post-test for experimental group is 460 and control group is 160 . Continued the calculation computation of mean scores for the experimental group is 15.33 and for the control group is 5.33.from that explanation it showed that the score of experimental group higher than control group.

To check the significant effect of the treatment, the researcher analyzed by using t-test formula. The result of t-test was 2.85 . Then, the researcher checked the critical value on the $t$ table of significant level $0,05 \%$ was 2.021 and $0,01 \%$ was 2.704 . From the result, it was found that t-test was higher than t-table $(2.85>2.021>2.704)$. It could be concluded that the null 
hypothesis was rejected and it can be inferred that the use of schema activation strategy was effective in teaching reading comprehension.

The researcher treatment the students were formulated into four steps. They were building interest and attention, accessing prior knowledge and exploring key words, building connection between students prior knowledge and the new material, and comprehending the new material. Those steps were so called steps in schema activation strategy. First, Building interest and attention, in teaching and learning reading, this activity became an important activity. Once the students were interested in the lesson, they felt at ease in understanding the lesson and learning reading ran well. The researcher selecting the topic also considered how far the topic could attract the students interest and how far the students were familiar with the topic. When the students were attracted and familiar with the topic, activating the students 'prior knowledge and exploring their vocabulary became easier.

The second steps was accessing prior knowledge and exploring key words. In this step, the researcher asked the students some questions related to the topic introduced. Those questions were about what the meaning of the topic was, what the students have already known about the text, and about things in the text. According to Willis (Willis, 1973), these activities belong to exploring key words. The purposes of this activity were improving the students' vocabulary and preparing them before reading new materials.

The third, building connection between students 'prior knowledge and the new material. The purpose of this step make students knew the importance of relating their prior knowledge to the new material. The researcher asked the students predict the text by looking at the title of the text. The activity was effective in making students used their prior knowledge in order to predict the content of the text.

The last step comprehending the new material, reading the text in depth became the activity in comprehending the new material. During the process of reading, the students read the text and connected it with their background knowledge. They were asked to find the new information they got from their reading like difficult words. In this step also the students were stimulated to relate what they had in their background knowledge to the new information in the text. It meant that there was interactive process during reading as it said by Brown (Torabi et al., 2017). Furthermore, the students were also presented a set of reading comprehension questions. It used to evaluate the students understanding toward the content of the text.

Comprehending the new material was the final step in Schema Activation Strategy. It was regarded to be successful as the students could accomplish the task well.

\section{CONCLUSION AND ADVICE}

Based on the result of the study, it could be concluded that the use of schema activation strategy was effective in teaching reading comprehension at the second grade students of MTs Tarbiyatul Mustafid. This skill has been proved by analyzing data from the result between the deviations of mean scores of experimental group was 15.33 and control group was 5.33. Then the result of the statistical analysis of t-test in this research was 2.85 . It was higher that critical values for t-table in degree of freedom (df) 58 is $2.021(0.05 \%)$ and $2.704(0.01 \%)$. From this fact, it was clear that mean score of both groups has a difference. It means the alternative hypothesis (Ha) was definitely accepted. From the result, the researcher concluded that the schema activation strategy was effective in teaching reading comprehension at the second grade students of MTs Tarbiyatul Mustafid. At the end of this chapter, the writer would like to propose some suggestion, which helpfully would be useful for all subjects. (1) For the Students, 
Reading comprehension is important for students since reading is a source of knowledge. By mastering reading comprehension students will master other language skill as well. So, the researchers are recommended to apply schema activation strategy as one of the ways in teaching reading comprehension because it can help the students in comprehending text easier. (2) For Teachers, The teacher should be creative in conducting teaching and learning process. There are many media, techniques or strategies which can be used in teaching English, especially reading comprehension. The teachers can practice the students" memory by giving them the opportunity to bring their prior knowledge in their reading process and monitor the students when they use their prior knowledge in order to encourage students to be more successful in reading. (3) For the researchers, The researcher knows that this research is far for being perfect. So, the researcher suggested for the future researchers who want to use schema activation strategy, it would be better if the next research is conducted in a longer period.

\section{REFERENCES}

Basyarudin, B. (2015). Filsafat bahasa sebagai fundamen kajian bahasa. Jurnal BAHAS Vol 26, No 1, 1-9. https://jurnal.unimed.ac.id/2012/index.php/bahas/issue/view/845

Ferlito, S., Bonomo, T., Costa, R., Di Salvo, M. M., Attanasio, L., Finocchiaro, P. M., Condorelli, M., \& Mazzone, D. (1996). Modificazioni di alcuni indici protrombotici dopo trattamento con iloprost in arteriopatici. Minerva Cardioangiologica, 44(12), 645-648.

Mardianti, T., Wibowo, I. S., \& Karim, M. (2016). Analisis Kesalahan Berbahasa dalam Karangan Siswa Kelas X AK 3 SMK Negeri 1 Kota Jambi. Pena, 6(2), 51-64. https://doi.org/10.1017/CB09781107415324.004

Muijs, D. (2012). Introduction to Quantitative Research. In Doing Quantitative Research in Education with SPSS (pp. 1-12). https://doi.org/10.4135/9781849209014.n1

Sugiyono. (2013). Buku - Sugiyono. In Metode Penelitian Kuantitatif, Kualitatif, dan $R \& D$ (p. 407).

Sugiyono. (2017). Sugiyono, Metode Penelitian. Penelitian, 34-45. https://doi.org/10.1021/ol7029646

Suharsimi;, A. (2013). Dasar-Dasar Evaluasi Pendidikan. In Jakarta: Bumi Aksara (p. 168).

Torabi, E., Behdani, M., Chafi, M. H., Moazzami, R., Sabatier, J., Khalaj, V., Shahbazzadeh, D., \& Bagheri, K. P. (2017). Characteristics and lethality of a novel recombinant dermonecrotic venom phospholipase D from Hemiscorpius lepturus. Toxins, 9(3). https://doi.org/10.3390/toxins9030102

Willis, H. (1973). A Brief Comment on the Utility of Scholarly-Traditional Grammar. College Composition and Communication, 24(2), 213. https://doi.org/10.2307/356514

Zimmerman, E. C. (1967). Imathia and Amblycnemus (Coleoptera: Curculionidae: Cryptorhynchinae). Pacif. Insects, 9, 187-196. 